\title{
ANALYSIS OF INTERFERENCES IN THE TRANSPORT OF PRISONERS WITH THE APPLICATION OF ISHIKAWA DIAGRAM
}

\author{
Monika ODLANICKA-POCZOBUTT ${ }^{1 *}$, Jakub SEMRAU ${ }^{2}$ \\ ${ }^{1}$ Silesian University of Technology, Faculty of Organization and Management, Institute of Management and \\ Logistics; monika.odlanicka-poczobutt@polsl.pl, ORCID: 0000-0001-7834-1188 \\ ${ }^{2}$ Silesian University of Technology, Faculty of Organization and Management, Institute of Management and \\ Logistics; jakub.semrau@polsl.pl, ORCID: 0000-0002-4894-7792 \\ * Correspondence author
}

\begin{abstract}
The transport system can initiate development activities in the economy if it can meet the expectations of users. A special type of transport is the transport of prisoners, carried out within the prison system. Due to the specific nature of this type of transport, the aim of the article was to analyze the interferences occurring in the process of transporting prisoners. The scope of research concerned the analysis of convoys and escorts of prisoners in one of the largest Polish custodial remands. The Ishikawa Diagram was used to diagnose the interferences.
\end{abstract}

Keywords: transport, process, prison system, Ishikawa Diagram.

\section{Introduction}

Nowadays, transport is an indispensable part of economic and social life. It refers to the movement of goods, persons and information in space, using specialized means of transport (Załoga, \& Kwarciński, 2019, p. 9). It consists in the provision of paid services from the point of view of transport economics, hence the basic division of transport into freight transport (cargo) and passenger transport (individual, collective) (Rydzkowski, Wojewódzka-Król, \& Babis, 2008, p. 1).

The transport system may initiate development activities in the economy if it can meet the expectations of users (Świderski, 2014, pp. 25-27). The detailed system of transport classification is very extensive ( $\dot{Z} \mathrm{ak}, 2009$, pp. 142-144).

One of the modes of passenger transport, in terms of accessibility to users, is individual transport, which is designed to meet the transport needs of a particular person or family and is characterized by a lack of regularity and specific communication conditions (Podoski, 1985, 
pp. 122-123). Public transport is understood as generally available passenger transport services, which are regularly carried out on a specific network or transport lines at specific intervals. Public transport services must be provided by marked means of transport, in a way visible to the passenger, and it is required to make public the tariff or price list of charges, rules of carriage of persons and luggage (Journal of Laws of 2018, item 2016). Statistical data indicate that, in 2017, 696,178 passengers (Statistics Poland) were transported by public transport in Poland.

A special mode of transport is the transport of prisoners, carried out within the prison system. Prison is the term used to describe all penal institutions and their organization or system of serving a sentence of imprisonment in a particular state. Modern legislation often uses the term penal institution instead of the term prison, and instead of the term prison system the penitentiary system (www.sw.gov.pl). A prisoner is a person who is remanded in custody, sentenced or punished, and the penitentiary unit where they are serving their sentence is a custodial remand or a penal institution. The prison system plays an important role in the efforts to ensure public order and safety. It protects the public from perpetrators of crimes sent to penal institutions and custodial remands.

The Prison Service, subordinate to the Minister of Justice (Journal of Laws of 2010, No. 79, item), is a uniformed and armed apolitical formation, having its own organizational structure, which carries out tasks related to the execution of preliminary custody and sentences of imprisonment, coercive measures resulting in imprisonment and service of imprisonment in the electronic surveillance system. It implements the provisions of the European Prison Rules, Standard Minimum Rules for the Treatment of Prisoners and the Convention for the Protection of Human Rights and Fundamental Freedoms, including ensuring that the rights of persons sentenced to imprisonment or under preliminary custody are respected. The Prison Service collaborates with other uniformed formations: Police, Fire Brigade, Border Guard, Internal Security Agency, Central Anti-corruption Bureau and Army.

The legality and regularity of the execution of sentence of imprisonment, sentence of custody and preliminary custody by the Prison Service are supervised by numerous state and international organizations. The control in this respect is exercised by: The European Committee for the Prevention of Torture and Inhuman or Degrading Treatment or Punishment (CPT), the Ombudsman and the National Prevention Mechanism under its authority, the Helsinki Foundation for Human Rights and penitentiary judges (www.sw.gov.pl).

The transport of prisoners may be carried out by law enforcement agencies or contract operators. The process of transportation in Poland takes place in a direct and indirect way, by means of convoy vehicles. Prisoners are usually transported at night, in order to minimize the risk and damage to the civilian population.

Due to the specific nature of this type of transport, the aim of the article was to analyze the interferences occurring in the processes of transporting prisoners. The scope of research concerned the analysis of convoys and escorts of prisoners in one of the largest Polish custodial remands. The Ishikawa Diagram was used to diagnose the interferences. 


\section{Transport of prisoners in Poland - general data, escorting and transport}

The prison system in Poland is a very important element of the state structure, as it increases the sense of security among citizens and contributes to the rule of law and order (Powałko, 2017). The transport of prisoners is quite risky, due to the fact that it means temporary introduction of dangerous prisoners into society, exposing the civilian population to the possibility of contact with them. The number of prisoners in custody - in preliminary custody, convicted and punished - in Poland is 74,077. The current summary for the years 2017-2018 is presented in Table 1.

Table 1.

Number of prisoners in preliminary custody, convicted and punished

\begin{tabular}{|c|c|c|c|c|c|c|c|c|c|c|}
\hline \multirow{3}{*}{ Date } & \multirow{2}{*}{\multicolumn{2}{|c|}{ All Together }} & \multirow{3}{*}{$\begin{array}{c}\text { Detained } \\
\text { On } \\
\text { Remand }\end{array}$} & \multirow{3}{*}{ Convicted } & \multirow{3}{*}{ Punished } & \multicolumn{5}{|c|}{ Including Women } \\
\hline & & & & & & \multicolumn{2}{|c|}{ All Together } & \multirow{2}{*}{$\begin{array}{c}\text { Detained } \\
\text { On } \\
\text { Remand }\end{array}$} & \multirow[b]{2}{*}{ Convicted } & \multirow[b]{2}{*}{ Punished } \\
\hline & 2017 & 2018 & & & & 2017 & 2018 & & & \\
\hline 31.01 .2018 & 72677 & 74896 & 7319 & 66554 & 1023 & 2654 & 2954 & 388 & 2488 & 78 \\
\hline 28.02 .2018 & 73470 & 75368 & 7466 & 66902 & 1000 & 2682 & 2998 & 394 & 2537 & 67 \\
\hline 31.03 .2018 & 74313 & 75657 & 7473 & 66902 & 992 & 2766 & 3075 & 405 & 2589 & 81 \\
\hline 30.04 .2018 & 73997 & 75101 & 7432 & 67192 & 1000 & 2767 & 3046 & 382 & 2584 & 80 \\
\hline 31.05 .2018 & 74030 & 74391 & 7450 & 66669 & 949 & 2791 & 2964 & 377 & 2538 & 69 \\
\hline 30.06 .2018 & 73858 & 74094 & 7393 & 65725 & 976 & 2849 & 3015 & 376 & 2570 & 69 \\
\hline 31.07 .2018 & 73736 & 73651 & 7273 & 65442 & 936 & 2861 & 3076 & 383 & 2610 & 83 \\
\hline 31.08 .2018 & 73417 & 73524 & 7394 & 65192 & 938 & 2813 & 3063 & 416 & 2577 & 70 \\
\hline 30.09 .2018 & 73717 & 73463 & 7552 & 64956 & 955 & 2836 & 3037 & 413 & 2570 & 54 \\
\hline 31.10 .2018 & 74154 & 73543 & 7543 & 65012 & 988 & 2837 & 3059 & 418 & 2566 & 75 \\
\hline 30.11 .2018 & 74490 & 73035 & 7476 & 64526 & 1033 & 2890 & 3017 & 404 & 2547 & 66 \\
\hline 31.12 .2018 & 73882 & 72204 & 7360 & 64045 & 799 & 2873 & 2940 & 405 & 2494 & 41 \\
\hline Average & 73807 & 74077 & 7428 & 66684 & 966 & 2802 & 3022 & 397 & 2586 & 69 \\
\hline
\end{tabular}

Source: Office for Information and Statistics CZSW.

The agencies are aware of the danger and always take additional security measures during transport, including securing vehicles and escort with additional officers. In most cases, prisoners who are transferred between penal institutions are moved by means of a road vehicle, specially designed for this purpose. Specialized vehicles for the transport of prisoners (Figure 1) are obliged to meet many security requirements, as many prisoners treat this time as an opportunity to escape. The most dangerous criminals are often subject to additional restrictions on mobility. Prisoners are usually transported at night, in order to minimize the risk and damage to the civilian population (Toronto, 1999).

Vehicles used for the transport of prisoners are modified or specially designed vehicles, such as vans or buses. These vehicles must be as safe as possible, with bulletproof glass, barred windows, separate compartments for escorting officers and a well-adapted prisoner compartment. In addition, the vehicle must be equipped with full radio communication, global positioning units, weapons and other emergency equipment. The vehicles are designed to transport prisoners from areas, such as the courthouse or penal institution, to another pre-arranged secured location. 


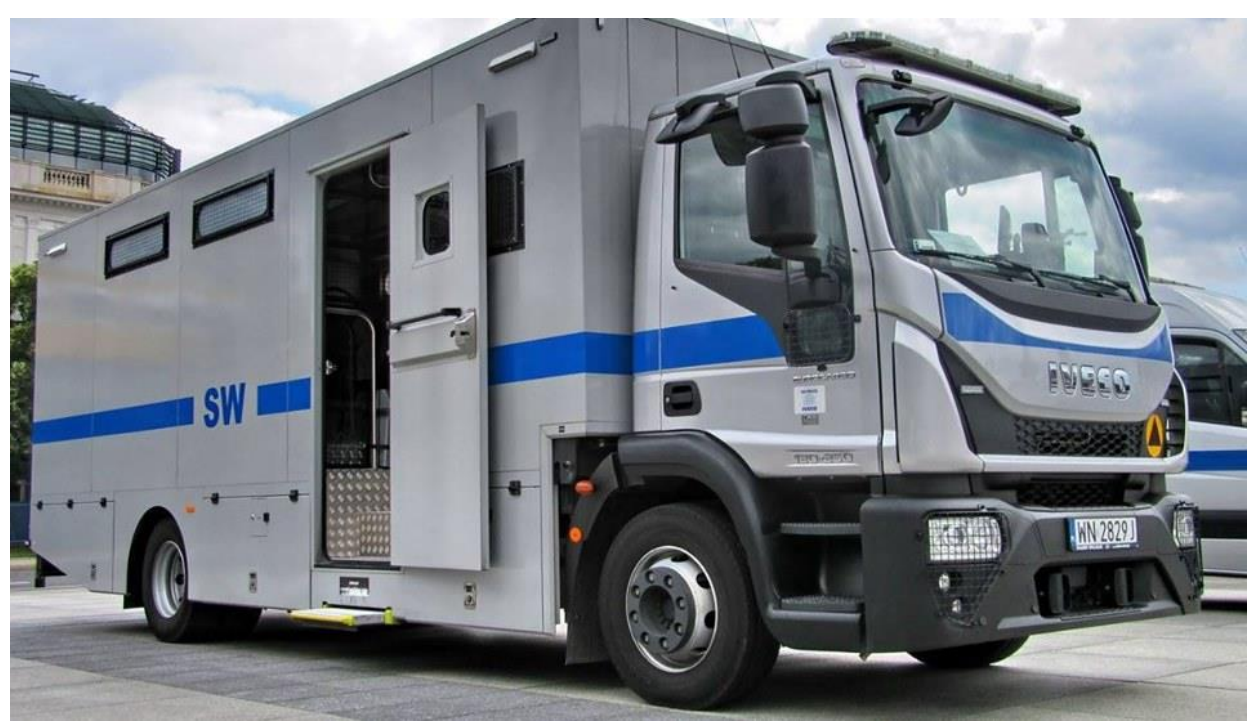

Figure 1. Vehicle used for the transport of prisoners. Source: https://www.sw.gov.pl/aktualnosc/ okregowy-inspektorat-sluzby-wieziennej-w-krakowie-nowe-oznakowanie.

As an additional safeguard against escape, prisoners are routinely searched to minimize the risk. The type of restrictions applied to a prisoner depends on their assessment during their stay in the penal institution. All prisoners are obliged to wear handcuffs during transport. Additional chain locks are often used to secure the prisoner's hands to the waist (Figure 2). They allow prisoners to make natural movements, but limit the possibility of lifting their arms. Chain locks can also be replaced by nylon or leather belts (Safe Prisoner Transport, www.policemag.com/...).

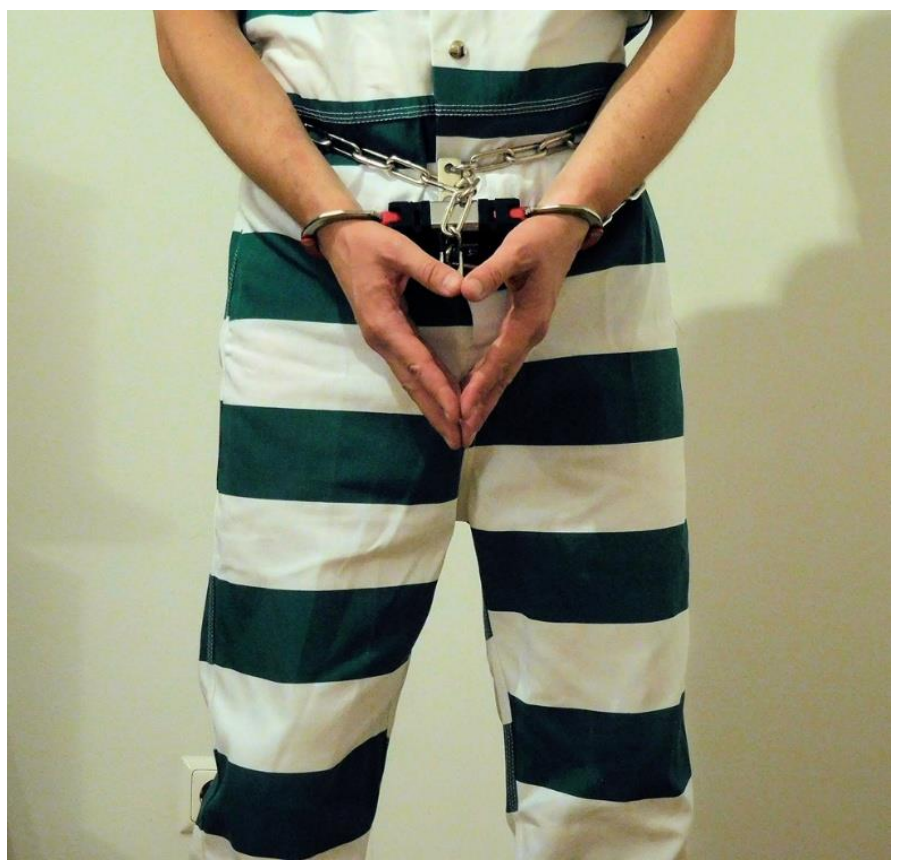

Figure 2. Chain lock. Source: https://en.wikipedia.org/wiki/Prisoner_transport. 
Prisoners during transport must, in most cases, wear a prison uniform that enables them to be identified immediately. In special cases, they are obliged to wear reflective-colored jackets.

The coordination, organization, documentation, preparation, reception and sending of prisoners is carried out using the Noe.NET system. This system is the most important IT system of the Prison Service, that supports the processes related to the transport of prisoners, preliminary custody and permanent imprisonment. Using the tools contained in the system, officers involved in the process of transporting prisoners can keep up to date with the state of transport operations (Chilmon, 2018).

The process of transportation in Poland takes place in a direct and indirect way, by means of convoy vehicles. Direct transport is characterized by the dominance of a single mode of transport, which takes place on the road directly to the destination. Indirect transport is transport which uses at least two means of transport (Koźlak, 2008, pp. 15-17).

The direct transport of prisoners may last from one to a maximum of three days, only in justified cases. The managing director, who receives a transport exceeding the specified time, is obliged to notify the district director. However, if the transport arrives from outside the district, it must inform the Director of the Information and Statistics Bureau of the Central Board, who immediately takes preventive action for future similar irregularities. Transport of prisoners may be carried out in stages if the prisoners need to stay in the penitentiary unit located along the route of the journey. In the case of forced stop, the Prison Service is obliged to provide the convoy commander with all assistance required to continue the transport. If it is not possible for the penitentiary unit to immediately transfer prisoners transported in stages to a new convoy vehicle, it is possible to wait up to 48 hours for the transfer (Regulation no. 29/2015). The number of transports of prisoners in Poland is more than 8,000 per year. The summary for 2017-2018 is presented in Table 2 and Figure 3.

Table 2.

Transports of prisoners in 2017-2018

\begin{tabular}{|c|c|c|c|c|c|c|}
\hline \multirow{2}{*}{ Month } & \multicolumn{2}{|c|}{ All Together } & $\begin{array}{c}\text { Including by } \\
\text { the Police }\end{array}$ & $\begin{array}{c}\text { Detained on } \\
\text { Remand }\end{array}$ & Convicted & Punished \\
\cline { 2 - 3 } & $\mathbf{2 0 1 7}$ & $\mathbf{2 0 1 8}$ & 1602 & 632 & 9385 & 140 \\
\hline January & 8891 & 10157 & 1409 & 1100 & 9893 & 237 \\
\hline February & 8811 & 11230 & 1508 & 553 & 8888 & 169 \\
\hline March & 9668 & 9610 & 1390 & 431 & 7402 & 127 \\
\hline April & 7647 & 7960 & 1396 & 478 & 7299 & 126 \\
\hline May & 7988 & 7903 & 1348 & 519 & 7546 & 145 \\
\hline June & 8433 & 8210 & 1145 & 454 & 7927 & 144 \\
\hline July & 7914 & 8555 & 1130 & 417 & 7835 & 142 \\
\hline August & 8863 & 8394 & 1304 & 392 & 7201 & 130 \\
\hline September & 8082 & 7723 & 1548 & 503 & 8658 & 181 \\
\hline October & 8265 & 9342 & 1572 & 520 & 6944 & 138 \\
\hline November & 8926 & 7602 & 1045 & 357 & 6153 & 116 \\
\hline December & 7017 & 6626 & 16397 & 6386 & 95131 & 1795 \\
\hline All Together & 100505 & 103312 & 1366 & 532 & 7928 & 150 \\
\hline Average & 8375 & 8609 & 1328 & & & \\
\hline
\end{tabular}

Source: Office for Information and Statistics CZSW, www.sw.gov.pl/ 


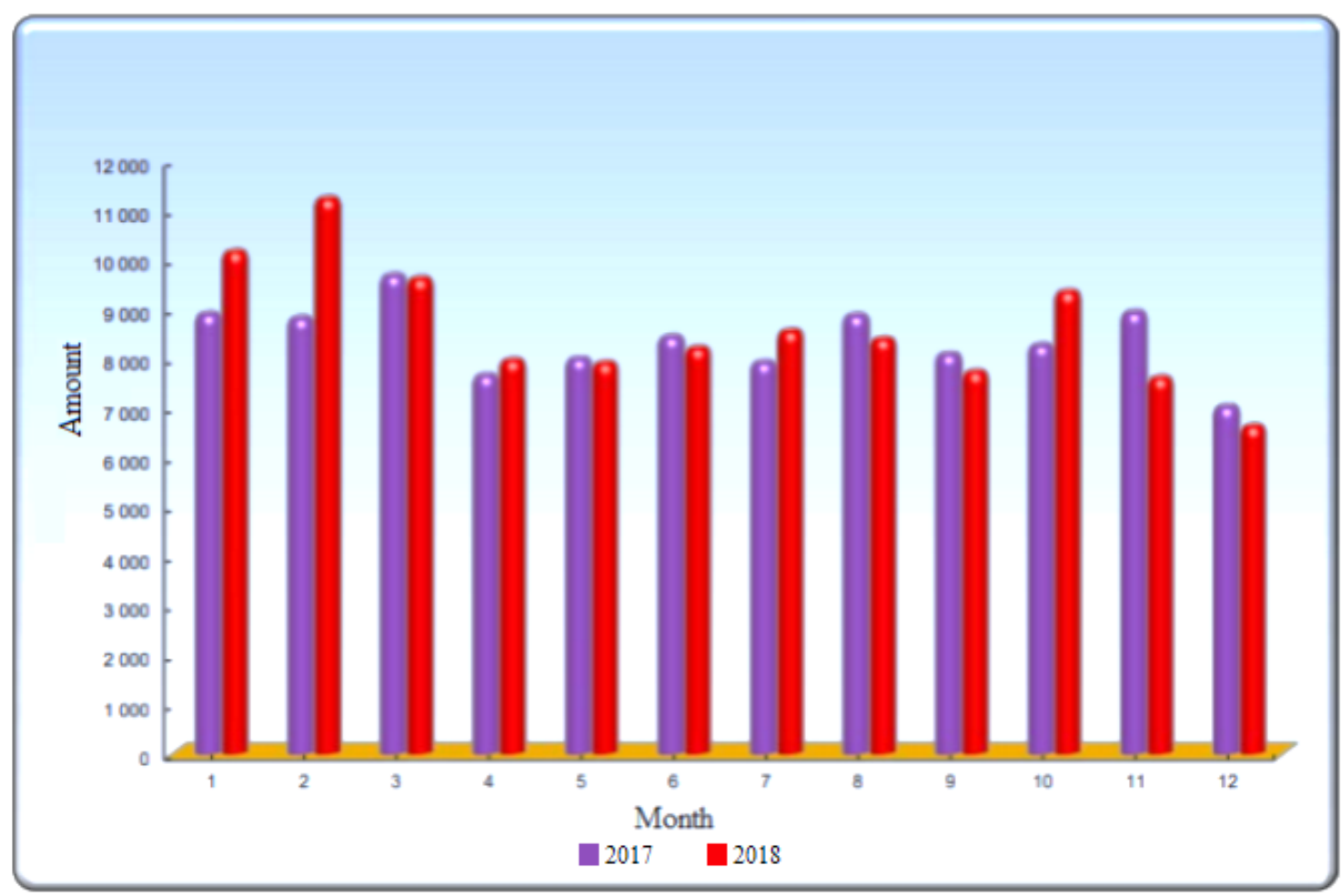

Figure 3. Transports of prisoners in 2017-2018. Source: Office for Information and Statistics CZSW, www.sw.gov.pl.

If it is not possible to transport the convict directly, the transfer takes place indirectly. The transport is directed to the intermediate penitentiary unit located along the route, which takes control of the convict and transports them to the destination unit (Regulation no. 29/2015).

A district inspectorate officer is responsible for the transport of convicts. The officer has the possibility to change the convoy vehicle and the route of the journey. If the officer has free places in the transport, they are obliged to transport the convicts temporarily staying in another unit, objects and documents, of which the right to possess by prisoners results from the provisions of the Penal Code.

Prisoners during transport should be escorted by a specified number of officers, armed with firearms, one of whom must be the convoy commander. The number of escorting officers is determined by assessing the risk of escape and the number of prisoners. Two officers may escort up to a maximum of ten prisoners. Until the escorting officers are appointed, the prisoner is transported by the State Police. The head of the prison is obliged to inform the police officers about the type of crimes committed by the convicts and inform the Ministry of Justice about the planning and sending of the transport each time.

Before the transport begins, the transport commander receives from the prison warden the prisoners' deposits, a list of the transported persons, working books and personal records. Convicts may take their own belongings with them after they have been searched by the Prison Service. 
Prisoners undergo medical examination after being qualified for transport and are provided with a set of provisions corresponding to their daily diet. The prison warden also informs prisoners about the regulations concerning the use of firearms by officers during the transport in threatening and dangerous situations before the transport begins (Journal of Laws No. 29, item 272, Section III. Escorting and transporting of prisoners $\S 78-89$ ).

The transported prisoners should not be exposed to public view. Each transport guarantees the prisoner protection against insults, publicity and curiosity of third parties (Ombudsman, p. 23).

\section{Case study}

In order to identify the threats occurring during the transport of prisoners, direct expert interviews were conducted with the employees of the selected custodial remand. The analyzed Custodial Remand is one of 70 such units in Poland. It is a key organizational unit of the Silesian Police, used by the Voivodeship Police Commander in Katowice to perform the tasks specified in the acts and executory regulations.

The custodial remand is located in the center of one of the largest and most populated cities in the Upper Silesian conurbation. The origins of the unit date back to 1868 . The capacity of the prison was set at the level of 412 prison places, meeting the law minimum of $3 \mathrm{~m}^{2}$ in a cell per prisoner. The remand is supervised by the Regional Inspectorate of Prison Service in Katowice, in the area resulting from the statutory functions of the supervisor of all police officers of the Silesian Voivodeship and the government administration unit. The analyzed custodial remand is one of the largest units of this type in the country.

The functioning efficiency of the Prison Service is determined by its mobility and the equipment used for transporting prisoners by officers and civilian employees. The efficiency of vehicles is controlled by specially qualified mechanics employed in the remand. Their task is to eliminate failures to the best of their abilities and to provide ongoing service to vehicles.

The currently analyzed remand has 27 transport vehicles, including:

- passenger cars - 16,

- vans -6 ,

- motorcycles -4 ,

- bus -1 .

The main activities related to transport, carried out by remand officers, include:

- escorting and convoying detainees to other penitentiary units,

- transport of special mail - materials marked as secret,

- transport of departmental materials, 
- transporting material evidence,

- ongoing maintenance of vehicles, removal of failures, carrying out periodic inspections.

The movement of prisoners in large units is significant. A distinction is made here between transfers in terms of take-overs, releases and transport between destinations. The Prison Service keeps statistics on the movement of detainees, classifying prisoners as received, released and transported. The transports in the period from 31.05.2018 to 31.05.2019 are shown in Figure 4.

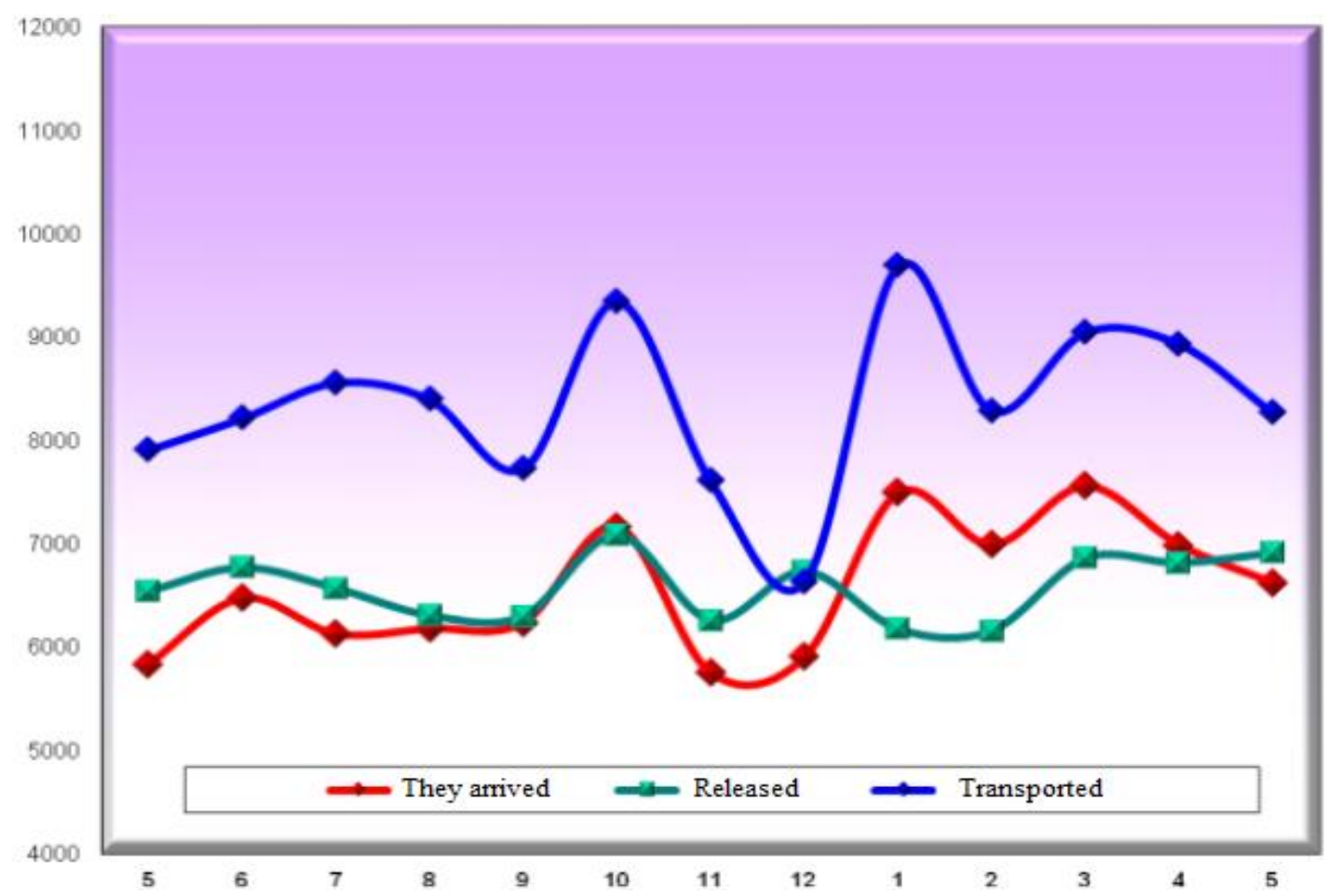

Figure 4. Movement of prisoners (persons received, released and transported) in the period from May 31, 2018, to May 31, 2019. Source: www.sw.gov.pl.

The analysis covered all officers employed in the analyzed entity. On the basis of information obtained through a direct interview, the Ishikawa Diagram was prepared, which is a method of imagining and grouping problems using a cause and effect chart (Mróz, 2017, p. 46; Gołaś, \& Mazur, 2010; Górny, 2013, pp. 27-43). The method, due to its characteristic appearance, sometimes referred to as the fish bone diagram, allows the identification of the causes of actual or potential failures of various types of undertakings and is used for analyses in the industry, but also in services, administration and project management.

Drawing up a diagram must be an effort of many employees of the organization, because the reasons for failure usually originate in various areas of activity. The analyzed team consisted of employees with extensive expertise, who additionally had the will to disclose the causes of defects, including those caused by themselves. 
The analysis consisted of the following stages:

\section{Identification of the problem}

The analysis of the issue under consideration was aimed at defining the problem. The brainstorming method was used. Officers participating in the interview pointed out the threats described as extraordinary, which included:

- attempted suicide or suicide of a transported convict,

- attempted murder or murder of an officer,

- an attempt on a person's health or life,

- an escape or attempted escape of a convoyed person.

The second stage was:

\section{Identification of the main groups of causes}

The identification of the main categories of causes that affect the identified problem has allowed the development of a group of causes. The officers pointed out a number of activities that are conducive to the above-mentioned incidents, such as:

- reckless, negligent and routine actions of officers,

- failure to carry out mandatory personal searches of prisoners,

- careless inspection of the premises for possible escape attempts,

- lack of vigilance on the part of officers,

- no tactics to be used during convoying,

- inadequate or non-existent supervision of convicts,

- incorrect application of direct coercive measures.

The last most frequently mentioned threat was the lack of a sufficient number of vehicles for the transport of prisoners, with separate compartments, and shortage of specialist direct coercive measures.

The third stage of the process involved:

\section{Detailed explanation of the causes}

Looking for causes and sub-causes for each identified group made it possible to state that, during transports, prisoners usually do not cooperate with officers, which generates a huge amount of threats. The officers participating in the interview pointed out that there is currently an insufficient amount of training for employees, due to lack of time and lack of financial resources. Occasionally, there are also failures of IT systems used to carry out transports of prisoners. On their basis, the key problems presented in the Ishikawa Diagram (Figure 5) were identified.

The Ishikawa Diagram was divided into five main categories of causes of problems during the execution of convoys and escorts: human resources, IT system, management, equipment and materials. 


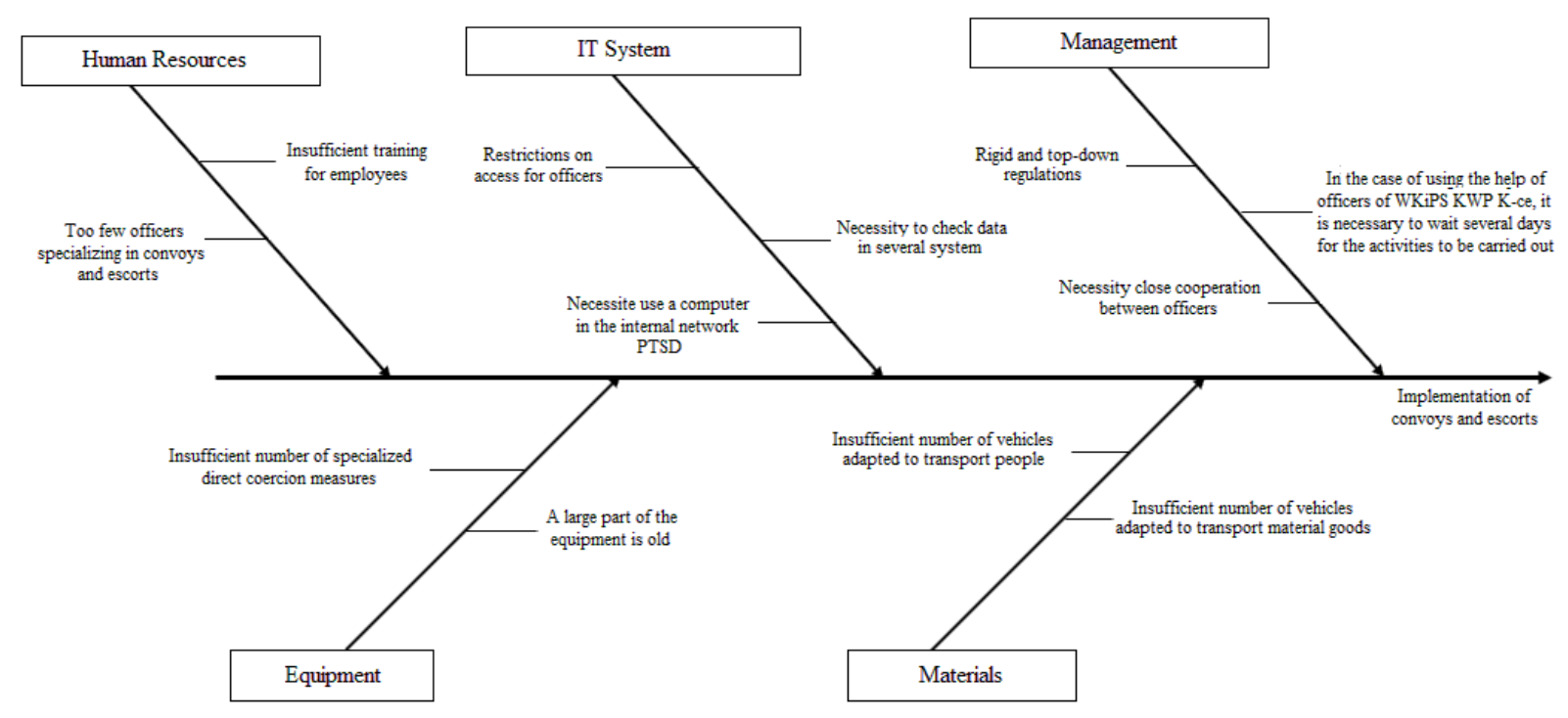

Figure 5. Ishikawa Diagram for the execution of convoys and escorts. Source: Ziemba, 2019.

The last stage included:

\section{Analysis of the results}

The detailed analysis of the diagram was designed to identify a number of causes that have the greatest impact on the final outcome and to formulate conclusions containing a description of corrective actions.

The key problems arising from the execution of convoys and escorts in the "Materials" category are insufficient number of vehicles adapted for the transport of material goods and insufficient number of vehicles adapted for the transport of prisoners. The biggest causes of the "Human Resources" problems are insufficient number of officers specializing in convoys and escorts and insufficient number of training courses for employees. In the "IT system" category, it can be noted that the problem, that may affect the execution of convoys and escorts, are limitations in access to the information system for officers, the need to check data in several systems and the need to have a computer present in the Police Data Transmission Network. However, in the "Management" category, most threats result from strict and top-down regulations and the need for close cooperation between officers in the event of using the assistance of the Voivodeship Police Headquarters in Katowice, where it is often necessary to wait several days for activities to be carried out. Insufficient number of specialist direct coercive measures and their age in the "Equipment" category have a significant impact on the occurrence of defects in the whole process.

The improvements proposed by the remand officers were specified on the basis of suggestions resulting from the interviews.

The first proposed improvement was to increase the time and money spent by officers on organizing training courses to improve the qualifications and quality of work, and thus the safety of transports. This would help to eliminate the lack of tactical knowledge necessary for the execution of convoys and increase officers' awareness of the dangers resulting from contact with convicts. Another proposed improvement was the purchase of new specialist direct 
coercion measures, which would eliminate many threats mentioned by officers in interviews. It was proposed that, in addition to traditional restrictions, hip belts with built-in stun guns used in the USA could also be used (Figure 6). In the event of an attack or attempted escape, the escorting officer has the right to activate the belt using a wireless remote control to overpower the prisoner (Stun Belt, http://www.stuntronics.com/band-it-1.html).

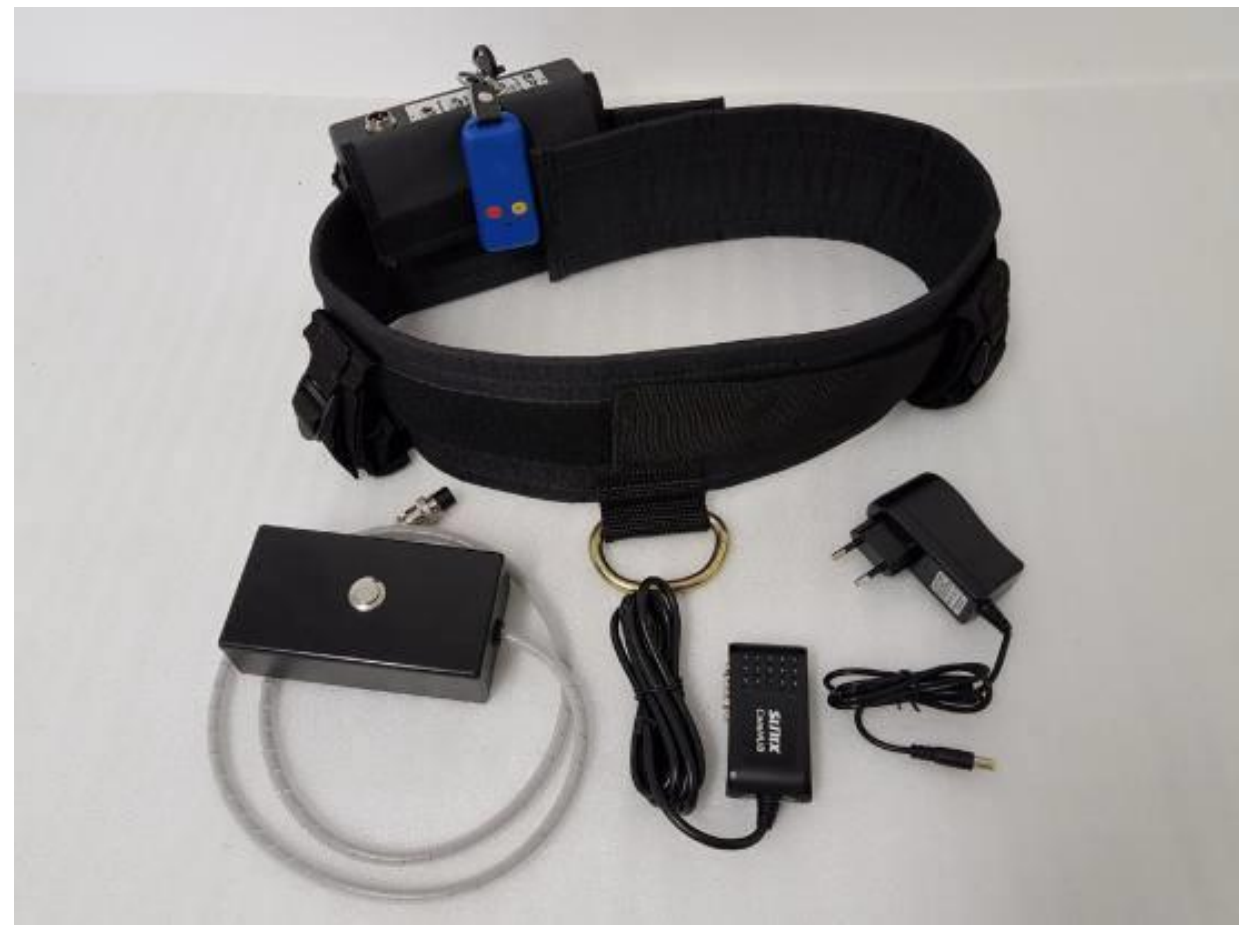

Figure 6. Belt with built-in stun gun. Source: https:/quantumball.com/2018/09/27/prisoner-anti-scapestun-belt/.

A further necessary improvement would be the purchase of more specialized vehicles to enable safe transport of prisoners. More financial resources are also needed for vehicles equipped with special compartments for the transport of prisoners, i.e. vans.

It should also be noted, that a large number of custodial remand vehicles are used as intervention vehicles and their availability is limited in the case of planned escorts and convoys.

\section{Conclusions and recommendations}

The aim of the article was to analyze the interferences occurring in the processes of transport of prisoners. The scope of research concerned the analysis of convoys and escorts of prisoners in one of the largest Polish custodial remands. In order to diagnose the key interferences, interviews with the prison staff were conducted, which allowed for the development of the Ishikawa Diagram. The diagram was used to graphically illustrate the main causes of the problems and to specify a wide range of threats that officers face during the execution of convoys and escorts. 
The main threats in the five categories of causes of problems are:

- Human resources:

○ too few officers specializing in convoys and escorts,

$\bigcirc$ insufficient training for employees.

- Materials:

○ insufficient number of vehicles adapted to transporting material goods,

$\circ$ insufficient number of vehicles adapted for passenger transport.

- IT system:

- restrictions on access for officers,

$\bigcirc$ the need to check the data in several systems,

$\circ$ the need to have a computer in the PDTN.

- Management:

0 in the event of using assistance from an officer of the Convoy and Judiciary Police Department of the Voivodeship Police Headquarters in Katowice, it is necessary to wait several days for the activities to be carried out,

- strict and top-down regulations,

$\circ$ the need for close cooperation between officials.

- Equipment:

$\bigcirc$ insufficient specialized direct coercion measures,

o a large part of the equipment is outdated.

The key threat, most frequently mentioned during expert interviews, was the shortage of quantitative and qualitative staff. The main problem was the inadequate training of employees and the lack of equipment in the remand. The proposed improvements were specified on the basis of suggestions made by officers during the interviews.

The recommendations made concerned increasing the time spent by officers and allocating increased financial resources to the organization of training to improve their qualifications and awareness of the dangers resulting from contact with convicts. It would also be important to purchase new specialist direct coercion measures, in order to eliminate many threats mentioned by officers. The purchase of a larger number of specialist vehicles, enabling safe transport of convicts, and a larger amount of funds for vehicles, equipped with special compartments for the transport of convicts, would be a helpful solution, especially as in the analyzed entity, the vehicles are often used as intervention vehicles and their availability is sometimes limited.

The main problems in increasing the number of custodial remand vehicles are often limited resources and centralized purchases in the police. The purchase of vehicles is based on the provisions of the Act on Public Procurement Law (Journal of Laws of 2004, No. 19, item 177). The purchase of vehicles exceeding the net value of PLN 126,747.00 must be carried out pursuant to the provisions of the Act. The procedure for selecting the contractor pursuant to the Act is based on the selection of the most advantageous offer among all those submitted to the tender procedure. The Police Logistics Office is responsible for supervising the tender process 
and developing standards of equipment and technical specifications, and the Transport Department of individual Voivodeship Police Units is responsible for the result. The complicated procedure significantly prolongs the time of purchase of new means of transport.

\section{References}

1. Chilmon, E. (2018). Rozwój systemów IT Stużby Więziennej. IT w administracji. Wrocław.

2. Gołaś, H., Mazur, A. (2010). Zasady, metody i techniki wykorzystywane w zarzadzaniu jakościa. Wydawnictwo Politechniki Poznańskiej, Poznań, 90.

3. Górny, A. (2013). Identyfikacja przyczyn zdarzenia wypadkowego. Zastosowanie diagramu Ishikawy do oceny pierwotnych i wtórnych przyczyn zdarzenia wypadkowego. Zeszyty Naukowe Wyższej Szkoty Zarządzania Ochrona Pracy w Katowicach, 1(9), 27-43.

4. https://en.wikipedia.org/wiki/Prisoner_transport.

5. https://quantumball.com/2018/09/27/prisoner-anti-scape-stun-belt/.

6. Koźlak, A. (2008). Ekonomika transportu. Teoria i praktyka gospodarcza. Gdańsk: Wydawnictwo UG.

7. Mróz, M. (2017). Diagram Ishikawy. Sposób na rozwiązywanie problemu. Wydawnictwo Internetowe $2 \mathrm{~K}$ Consulting.

8. Podoski, J. (1985). Transport $w$ miastach. Warszawa: Wydawnictwa Komunikacji i Łączności.

9. Powałko, O. (2017). System więziennictwa w Polsce a bezpieczeństwo wewnętrzne. Obronność, Zeszyty Naukowe, 2(22).

10. Roczna Informacja Statystyczna za rok 2018. Ministerstwo Sprawiedliwości, Centralny Zarzą Stużby Więziennej (2018). Warszawa, BIS.0332.17.2018.AP.

11. Rozporządzenie Ministra Sprawiedliwości z dnia 20 czerwca 1931 r. w sprawie regulaminu więziennego. Dz. U. R. P. Nr. 29, poz. 272 (Rozdział III. Eskortowanie i transport więźniów, $\S 78-89)$.

12. Rydzkowski, W., Wojewódzka-Król, K., Babis, H. (2008). Transport. Warszawa: PWN.

13. Rzecznik Praw Obywatelskich Prawo Więźniów - dorobek społeczności międzynarodowej.

14. Safe Prisoner Transport, www.policemag.com/340950/safe-prisoner-transport, 25.06.2019.

15. Statistics Poland, www.stat.gov.pl/obszary-tematyczne/transport-i-lacznosc/transport/ przewozy-ladunkow-i-pasazerow-w-2017-roku,11,6.html/.

16. Statystyka bieżaca - Służba Więzienna, www.sw.gov.pl, 13.07.2019.

17. Stun Belt, http://www.stuntronics.com/band-it-1.html, 25.06.2019. 
18. Świderski, A. (2014). Wybrane aspekty jakości publicznego transportu pasażerskiego. Logistyka - Nauka, 4.

19. Toronto Police Service (1999). Annual Report Prisoner Transportation, www.web.archive.org/web/20110103030722/http://www.torontopolice.on.ca/publications /files/reports/1999annualreport/prisonertransport.html, 24.06.2019.

20. Ustawa z dnia 16 grudnia 2010 r. o publicznym transporcie zbiorowym, DzU 2018, poz. 2016.

21. Ustawa z dnia 29 stycznia 2004 r. Prawo zamówień publicznych, DzU 2004, nr 19, poz. 177.

22. Ustawa z dnia 6 czerwca 1997 r. Kodeks Karny Wykonawczy, DzU 1997, nr 90, poz. 557.

23. Ustawa z dnia 9 kwietnia 2010 r. o Służbie Więziennej, DzU 2010, nr 79, poz. 523.

24. Zadania i usprawnienia SW, https://www.sw.gov.pl/strona/zadania-i-uprawnienia-sw, 14.07.2019.

25. Żak, J. (2009). Transport. In: D. Kisperska-Moroń, S. Krzyżaniak (eds.), Logistyka. Poznań: Instytut Logistyki i Magazynowania.

26. Załoga, E., Kwarciński, T. (2019). Pasażerski transport regionalny. Warszawa: PWN.

27. Zarządzanie Nr 29/2015 Dyrektora Generalnego Służb Więziennej z dnia 1 lipca 2015 r. w sprawie transportowania skazanych.

28. Ziemba, P. (2019). Problemy realizacji procesów logistycznych $w$ zakresie działań dochodzeniowo-śledczych $i$ prewencyjnych na przykładzie Komendy Miejskiej Policji w Gliwicach. Praca magisterska. Zabrze: Politechnika Śląska. 